\title{
The Investigation of the Impact of Auditor tenure and Audit Firm Size on Accounting Conservatism in Financial Reporting of Firms Listed in Tehran Stock Exchange (TSE)
}

\author{
Saeid Khodayar -e- Yeganeh ${ }^{1}$, Saeid Jabbarzadeh Kangarlouei ${ }^{2, *}$, Morteza Motavassel $^{3}$ \\ ${ }^{1}$ Sama Technical and Vocational Training College, Islamic Azad University, Urmia Branch, Urmia, Iran \\ ${ }^{2}$ Department of Accounting, Urmia Branch, Islamic Azad University, Urmia, Iran \\ ${ }^{3}$ Department of Accounting, West Azarbyjan Science and Research Branch, Islamic Azad University, West Azarbyjan, Iran \\ Jabbarzadeh.s@gmail.com
}

\begin{abstract}
Although audit quality and accounting conservatism are separate issue in financial reporting and accounting and audit scope, each has an important impact on capital market efficiency. However, this study tries to answer as to whether audit quality, characterized by audit firm size and auditor tenure, of firms listed in TSE could have a significant effect on accounting conservatism in financial reporting quality. To find an appropriate answer, after hypotheses development and collecting data for the period of 2002 to 2010 , the hypotheses are tested. The results of hypotheses test show that audit quality including audit firm`s size and auditor tenure does not affect conservatism in financial reporting of firms listed in (TSE). This result may stem from the fact that managers have no conservative behavior in financial reporting so audit quality may not be an effective factor on manager's conservative behavior in financial reporting.
\end{abstract}

Keywords Audit Quality, Accounting Conservatism, Financial Reporting, Audit Size, Auditor Tenure

\section{Introduction}

High-profile corporate failures that occurred at the beginning of this century have raised concern about the reliability of companies' financial statements. While most agree that the primary responsibility for preparing accurate financial statements rests with company management and boards, questions also have been raised about the quality and independence of external auditors. Regulators and standard-setters have attempted to enhance audit quality through rules affecting auditor. Mandatory rotation of audit firms for a particular audit client is suggested as a means of improving audit quality through maintained independence and new "fresh eyes" on audits independence[1]. The importance of auditor independence, in fact and in appearance, is widely accepted in theory and practice[2]. Reseachers argue that permitting an unlimited period of association between audit firms and their clients threats independence $[3,4]$. In addition, larger auditors are more competent and/or independent (and so provide higher-quality services) than smaller auditors, and they have more to lose when an

* Corresponding author:

jabbarzadeh.s@gmail.com (Saeid Jabbarzadeh Kangarlouei)

Published online at http://journal.sapub.org/ijfa

Copyright (C) 2012 Scientific \& Academic Publishing. All Rights Reserved audit failure occurs[5]. Reference[6] argues that audit firm size affects audit quality and defines audit quality as the probability that the auditor discovers and reports a material misstatement in the financial statements. Recently, audit quality has been defined in terms of the level of assurance that the auditor obtains[7]. Figure 1 presents the determinants of audit quality.

On the other hand, conservatism is one of the most prominent characteristics of financial accounting, which has influenced accounting practices for centuries[8]. Conservatism is defined as capturing accountants' tendency to require a higher degree of verification for recognizing good rather than bad news in earnings[9,10]. Reference[11] define conservatism as the accounting choices in uncertainties, which lead to understatement of assets and revenues and overstatement of expenses. Reference[12] defines conservatism as "a prudent reaction to uncertainty to try to ensure that uncertainties and risks inherent in business situations are adequately considered. Thus, if two estimates of amounts to be received or paid in the future are about equally likely, conservatism dictates using not for redistribution the less optimistic estimate; however, if two amounts are not equally likely, conservatism does not necessarily dictate using the more pessimistic amount rather than the more likely one. Conservatism no longer requires deferring recognition of income beyond the time that adequate evidence of its exis- 
tence becomes available or justifies recognizing losses before there is adequate evidence that they have been incurred". Despite the unquestionable influence of conservatism, disagreement remains about what economic demands lead to financial reporting conservatism. Research examining lenders' demands for reporting conservatism has been questioned for ignoring conservative contract modifications[13]. Recent empirical research on conservatism suggests not only accounting practice is conservative, but also that it has become more conservative in the last 30 years. These results are surprising given the vocal opposition of many capital market regulators, standard-setters and academics to conservatism. One explanation is that conservatism arises because it is part of the efficient technology employed in the organization of the firm and its contracts with outside parties (contracting explanation). Under this explanation, conservative accounting is a means of addressing problems due to parties to the firm having asymmetric information, asymmetric payoffs and limited liability[10]. This is due to the fact that conservative accounting methods place constraints on the distribution of those net assets thereby limiting the scope for self-serving opportunistic behavior. For example, conservative accounting may help in aligning the interests of managers and shareholders through its impact on accounting earnings measures that are frequently used in management compensation contracts[14]. In recent years, shareholder litigation is another potential source of conservatism. Litigation also produces asymmetric payoffs: overstating net assets is more likely to generate litigation costs than understating net assets. Conservatism, by understating net assets, reduces the firm's expected litigation costs[10].

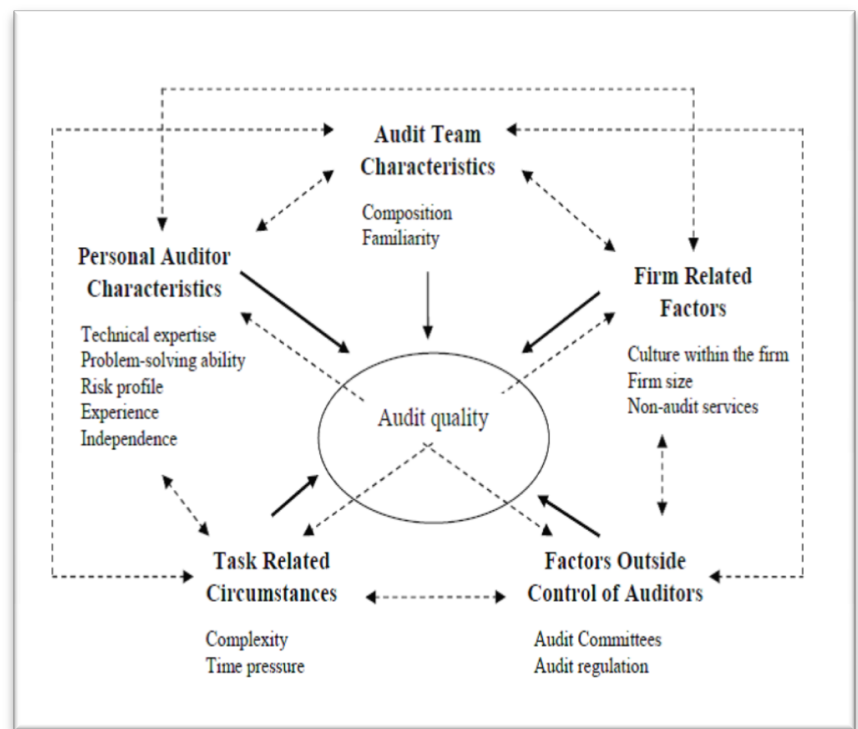

Source:[7]

Figure 1. An overview of the determinants of audit quality

The separation of ownership and control of the firm leads to information asymmetries between owners and managers of the firm[15]. As we can understand from mentioned notes, both conservatism and audit are means to reduce information asymmetry. However, is it expected that both increase financial reporting quality through increasing the reliability of financial reporting. Therefore, this study tries to answer as to whether audit quality of firms listed in TSE could have a significant effect on accounting conservatism in financial reporting quality.

\section{Literature Review}

Some argue that with increasing auditor tenure, conservatism reduces. They assert that in the first years of an audit work with new auditee, auditors may be afraid of bringing charges as a result of un acquaintance with audit activities so request more conservative procedures from employer. However, as development of relationships and independence reduction they do not have tendency to be against management wills from audit so managers' report optimistically[16,17]. This is while others argue that auditor and auditee long run relationship lead to more conservatism by auditors. They demonstrate that new auditors have no acquaintance with business activities and internal control systems of audit and rely on management decisions about financial reporting so there is a possibility of allowing opportunistic behavior of managers. This may lead to less conservatism. However, with increasing auditor tenure and more acquaintance they avoid potential audit risk and utilize accounting conservatism as a strategy for risk management. Early recognition of bad news regarding future cash flows than good news may be a safeguarding tool against bringing charges to the auditors. Other strategies like increasing audit fee to compensate increasing risk of bringing charges and exit from risky auditing may be costly and inefficient[18].

As it is shown in above, although the results of researches regarding the relationship between research variables show a relationship between variables, these results are contrary.

Reference[19] suggests that conservatism mitigates information asymmetry. Specifically, the level of accounting conservatism is positively related to the level of information asymmetry, and information asymmetry in the current period will further drive an increase of conservatism in the next period. Thus, their findings question the decision of IASB and FASB conservatism exclusion from the qualitative characteristics of accounting information. They conclude that the necessity for accounting conservatism is greater for firms whose auditors have longer tenure. They assert that since conservatism is excluded from the qualitative characteristics of accounting information, shareholders should keep a more careful eye on the issue of information asymmetry. Their findings further suggest that, especially in cases of longer auditor tenure, conservatism should be encouraged, not excluded. In this regard,[20] shows that FASB reason for eliminating conservatism from the joint conceptual framework is flawed from the contracting perspective. In addition,[21] manifests that it is puzzling why the notion of conservatism becomes deeply ingrained in financial state- 
ments despite the efforts of standard setters over the decades to change it. All of these indicate scholars concern regarding accounting conservatism elimination from qualitative characteristic of conceptual framework, which on its own, leads to mitigating financial reporting quality.

Reference[22] investigated the relationship between accounting conservatism and voluntary corporate governance mechanisms. They find that voluntary audit committee formation, increasing board independence and decreasing board size are positively associated with unconditional accounting conservatism and negatively related to the degree of conditional conservatism. Their results support the contention that firms voluntarily adopting perceived best practice corporate governance mechanisms employ unconditional accounting conservatism as a complimentary agency control device and are consistent with the observed negative association between the unconditional and conditional forms of accounting conservatism practice. Reference[1] investigated as to whether auditor tenure affect accounting conservatism and found that the positive association only exists for large firms or firms strongly monitored by their auditors, while for smaller firms or firms weakly monitored by their auditors, he observed a significantly negative association between auditor tenure and conservatism. Overall, his findings suggest that client importance plays an important role in long-term auditor-client relationship. Long-term auditor-client relationship imposes greater threat to auditor independence for smaller clients weakly monitored by auditors than larger clients do. Reference[23] present evidence that auditor tenure and non-audit services are positively associated with earnings conservatism. Their results are robust even after controlling for company size, leverage and growth. They further examine the influence of government-linked companies on the relationship between (1) auditor tenure, (2) provision of non-audit services, and earnings conservatism and find that their main results hold for non-government linked companies. For government-linked companies, they find no association between auditor tenure and earnings conservatism, while the provision of non-audit services is negatively associated with earnings conservatism. This result implies that high provision of non-audit services to government-linked companies lead to impairment of auditor independence. They also show that auditor tenure and provision of non-audit services are associated with higher earnings conservatism, regardless of whether the companies are audited by industry specialist or non-industry specialist. Reference[18] show that there is a significant relationship between auditor tenure and conservative earnings. Reference[24] find that firms with long term auditor tenure (13 and 15 or more) may report discretionary accruals to meet forecasted earnings. Reference[25] in a research titled "mandatory audit firm rotatio: fresh look versus poor knowledge" indicate that when firms are looking for auditors according to their appetite, Mandatory audit firm rotation increase investment efficiency in these firms. Reference[26] focusing on two auditor characteristics; auditor size and auditor industry specialization and two auditor-client rela- tionship characteristics; auditor tenure and the auditor's opinion find that auditor size, industry specialization, tenure and type of auditor opinion are important determinants of audit quality. Using auditors' propensity to issue a modified audit opinion

(MAO) as a proxy for audit quality,[27] find that firms with mandatory audit partner rotations are associated with a significantly higher likelihood of an MAO than are no-rotation firms. However, they find that this effect is restricted to firms located in less developed regions. Reference[28] in a reseach titled "do the Big 4 and the Second-tier firms provide audits of similar quality" find little difference in actual audit quality but a more pronounced difference in perceived audit quality.

\section{Hypotheses Development}

This study tries to answer as to whether audit quality, characterized by audit firm size and auditor tenure, of firms listed in TSE could have a significant effect on accounting conservatism in financial reporting quality. To find an appropriate answer, one main hypothesis and two sub-hypotheses are developed as following:

Main hypothesis: audit quality, characterized by audit firm size and auditor tenure, has a significant effect on accounting conservatism in financial reporting quality of firms listed in TSE.

\section{Sub-hypotheses:}

Sub-hypothesis 1- audit firm's size has a significant effect on accounting conservatism in financial reporting quality of firms listed in TSE.

Sub-hypothesis 2- auditor tenure has a significant effect on accounting conservatism in financial reporting quality of firms listed in TSE.

\section{Population and Sampling}

The population of this study consists of firms listed in TSE. However, due to high volume of population and heterogeneity among firms listed in TSE, following conditions are considered:

1. Firms must have accepted since 2002 in TSE.

2. Firm's fiscal year must be ended at the end of year and they have not changed their fiscal year during studied period.

3. Firms must not be brokerage or investment firm.

As a result of these conditions, sample of 130 firms is obtained and finally through systematic elimination sampling 92 firms are selected to be studied during 2002 to 2010.

\section{Methodology and Variables}

Since the study tries to find a significant relationship between audit quality and accounting conservatism in financial reporting quality of firms listed in TSE, the research is cor- 
relation study. On the other hand, the study is ex post facto (casual-comparative) and it is applied study since the wide range of financial information users can utilize it. In addition, it should be considered as a positive research in accounting when it is related to the capital market. It worth to notice that audit quality is considered as independent variable, accounting conservatism in financial reporting quality as dependent variable and also leverage, firm`s size and sales growth as control variable.

\section{Statistical Models and Test Methods}

Auditor firm's size: the classification conducted by Iranian Certified Accountant Association in 2009, classified firms according to their income, is used for measuring firm's size.

Auditor tenure: to quantify auditor tenure, firstly total 9 years divided into three periods of 3 years. Then, if firm has no audit rotation it takes 1, 0 otherwise. Mean of contributed scores for each firm calculated so firm may face four positions as following:

1 shows that no audit rotation in three periods of 3 years and or maximum one time audit firm rotation in one of three years in total 9 years.

0.67 shows one time audit firm rotation in total 9 years.

0.33 shows two times audit firm rotation in total 9 years.

Zero shows three times audit firm rotation in total 9 years.

\section{Models of Accounting Conservatism Measurement}

According to[29] different reporting features may result in asset understatement. One such feature is the selection of "conservative" accounting methods. For example, asset understatement results from the choice to expense investments in certain assets (e.g., R\&D) or accelerate the recognition of certain costs (e.g., through use of accelerated depreciation or LIFO). The mirror image of an understatement of net assets on the balance sheet (also known as "balance sheet conservatism") is a corresponding reduction in income ("income statement conservatism"). The balance sheet effect may persist over time as exemplified by the systematic understatement of expensed intangibles. However, the income statement effect is inherently reversible. A second reporting feature that results in the understatement of net assets is the asymmetric timeliness of recognizing gains and losses. The first reporting feature is also referred to in the literature as "unconditional conservatism" and the latter feature as "conditional conservatism." Reference[11] define conservatism as the accounting choices in uncertainties, which lead to understatement of assets and revenues and overstatement of expenses. They use discretionary accruals because it is means to exercise conservatism and also management discretion in uncertainties sets tone for conservatism. Total accruals and discretionary accruals are measured as following:

$\mathbf{A C C}_{\mathrm{it}}=\left(\mathrm{NI}_{\mathrm{it}}+\mathrm{DEP}_{\mathrm{it}}\right)-\mathrm{CFO}_{\mathrm{it}}$

$\mathbf{O A C C}_{\mathrm{it}}=\Delta\left(\mathrm{AR}_{\mathrm{it}}+\mathrm{I}_{\mathrm{it}}+\mathrm{P}_{\mathrm{it}}\right)-\Delta\left(\mathrm{AP}_{\mathrm{it}}+\mathrm{TP}_{\mathrm{it}}\right)$

NOACC $C_{i t}=A_{\text {CC }}-\mathrm{OACC}_{\text {it }}$

Where:

ACC: total accrual, NI: net income before extraordinary items, DEP: depreciation, CFO: operating cash flows, OACC: operating accruals (non-discretionary), AR: receivables, I: inventories, P: prepayments, TP: tax prepayments, NOACC: non-operating accruals (discretionary)

The results of[11] show that by passing each year non-operating accruals become significantly smaller, in other word, become more conservative. This means that managers choose methods to minimize retained earnings in long term. They argue that accruals are a measure of changes in conservatism during long term and more accruals lead to less conservatism and vice versa, therefore, to measure conservatism changes, accruals multiplied by negative one as following:

Conservatism $=($ Operating accruals $/$ total assets at the beginning of period $) *(-1)$

Operating accruals $=$ operating profit $-\mathrm{CFO}$

\section{Empirical Results}

Descriptive statistics of reseach variables is presented in Table 1.

Table 1. descriptive statistics

\begin{tabular}{|c|c|c|c|c|c|c|}
\hline & $\mathrm{CON}$ & AZ & $\mathrm{AT}$ & $\overline{F L}$ & FS & $\mathrm{G}$ \\
\hline Mean & -.036 & .1512 & .6797 & .6964 & 7.685 & .1822 \\
\hline Median & -.029 & .0185 & .6700 & .6950 & 7.628 & .1470 \\
\hline Mode & -.05 & .48 & 1.00 & .69 & 7.00 & .10 \\
\hline $\begin{array}{l}\text { Std. Devia- } \\
\text { tion }\end{array}$ & .1284 & .2138 & .3234 & .2043 & .5662 & .3764 \\
\hline Variance & .017 & .046 & .105 & .042 & .321 & .142 \\
\hline Skewness & -.405 & .907 & -.728 & 1.319 & .200 & 4.189 \\
\hline Kurtosis & .795 & -1.177 & -.497 & 7.158 & -.142 & 45.32 \\
\hline Minimum & -.50 & .00 & .00 & .16 & 6.20 & -.91 \\
\hline Maximum & .36 & .48 & 1.00 & 1.99 & 9.30 & 4.97 \\
\hline
\end{tabular}

Where: CON is conservatism, AZ is audit firm size, AT is auditor tenure, FL is financial leverage, FS is firm's size and $\mathrm{G}$ is growth.

Sub-hypothesis 1- audit firm's size has a significant effect on accounting conservatism in financial reporting quality of firms listed in TSE.

Table 2. Summary results of regression model

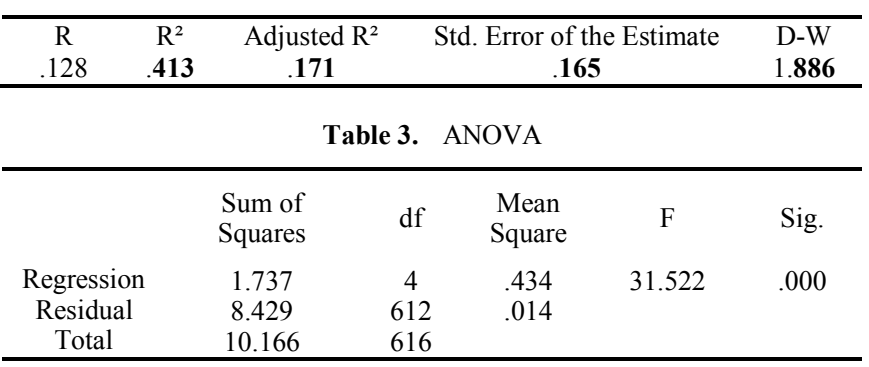


Table 4. Coefficients

\begin{tabular}{|c|c|c|c|c|c|c|c|}
\hline \multirow{4}{*}{$\begin{array}{l}\text { Constant } \\
\text { AZ }\end{array}$} & \multicolumn{2}{|c|}{ Unstandardized Coefficients } & \multirow{2}{*}{$\begin{array}{c}\text { Standardized Coefficients } \\
\text { Beta }\end{array}$} & \multirow[b]{2}{*}{$\mathrm{t}$} & \multirow{2}{*}{ Sig. } & \multicolumn{2}{|c|}{ Collinearity Statistics } \\
\hline & B & Std. Error & & & & Tolerance & VIF \\
\hline & -.246 & .079 & & -3.110 & .002 & & \\
\hline & .016 & .022 & .026 & .704 & .482 & .982 & 1.018 \\
\hline $\mathrm{FL}$ & .119 & .025 & .189 & 4.733 & .000 & .850 & 1.176 \\
\hline $\mathrm{FS}$ & .019 & .009 & .084 & 2.097 & .036 & .839 & 1.192 \\
\hline $\mathrm{G}$ & -.125 & .013 & -.368 & -9.984 & .000 & .999 & 1.001 \\
\hline
\end{tabular}

Table 5. Summary results of regression model

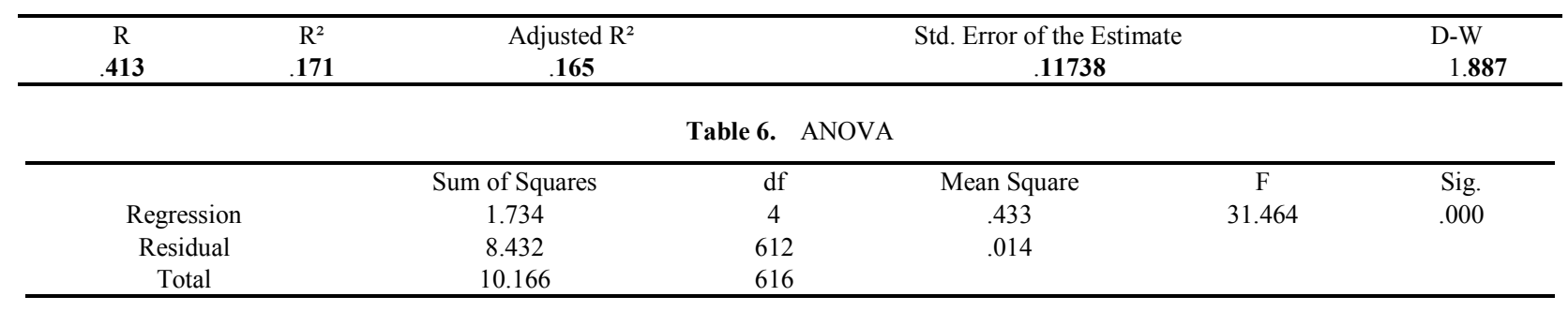

Table 7. Coefficients

\begin{tabular}{|c|c|c|c|c|c|c|c|}
\hline & \multicolumn{2}{|c|}{ Unstandardized Coefficients } & \multirow{2}{*}{$\begin{array}{c}\text { Standardized Coefficients } \\
\text { Beta }\end{array}$} & \multirow[b]{2}{*}{$\mathrm{t}$} & \multirow{2}{*}{ Sig. } & \multicolumn{2}{|c|}{ Collinearity Statistics } \\
\hline & B & Std. Error & & & & Tolerance & VIF \\
\hline Constant & -.241 & .078 & & -3.075 & .002 & & \\
\hline AT & .008 & .015 & .020 & .548 & .584 & .994 & 1.006 \\
\hline FL & .119 & .025 & .189 & 4.738 & .000 & .851 & 1.176 \\
\hline FS & .018 & .009 & .080 & 1.998 & .046 & .850 & 1.177 \\
\hline G & -.126 & .013 & -.369 & -9.991 & .000 & .996 & 1.004 \\
\hline
\end{tabular}

To investigate the amount of independent variable effect on dependent variable, multiple linear regression is used and the results is presented as following:

According to Table 2, R, $\mathrm{R}^{2}$ and adjusted $\mathrm{R}^{2}$ are $0.413, .171$ and 0.165 , respectively, indicating no or a very weak correlation between variables. According to Table 2, significance level is less than 5 percent; therefore, linear relationship between two hypotheses is accepted. Overall, considering significant level of audit firm size (0.482) null hypothesis is accepted and alternative hypothesis is rejected showing that audit firm size has no significant effect on accounting conservatism in financial reporting quality of firms listed in TSE.

Sub-hypothesis 2-auditor tenure has a significant effect on accounting conservatism in financial reporting quality of firms listed in TSE.

To investigate the amount of independent variable effect on dependent variable, multiple linear regression is used and the results is presented as above.

According to Table 5, R, $\mathrm{R}^{2}$ and adjusted $\mathrm{R}^{2}$ are $0.413, .171$ and 0.165 , respectively, showing no or a very weak correlation between variables. According to Table 5, significance level is less than 5 percent; therefore, linear relationship between two hypotheses is accepted. Overall, Overall, considering significant level of auditor tenure (0.584) null hypothesis is accepted and alternative hypothesis is rejected showing that auditor tenure has no significant effect on accounting conservatism in financial reporting quality of firms listed in TSE.

\section{Conclusions}

This study tries to answer as to whether audit quality, as characterized by audit firm size and auditor tenure, of firms listed in TSE could have a significant effect on accounting conservatism in financial reporting quality. To find an appropriate answer, after hypotheses development and collecting data for the period of 2002 to 2010, the hypotheses are tested. The results of hypotheses test show that audit quality, as characterized by audit firm size and auditor tenure, does not affect conservatism in financial reporting of firms listed in (TSE). This result is inconsistent with the most of previous studies espcially in the US[1,23,24]. However, according to[30] this may stem from less litigious environments, which in that this study is coducted. This inconsistent result stem from difference between countries is reported also by[31] who find there may be no difference in audit quality between Big Six and non-Big Six auditors in Korea.

Further, to explore this non-relation, presence of conservative behavior in the Iranian firms is investigated. To do so, the level of conservatism during this study is presented by following illustration. As we can see in the illustration, the level of conservatism exercise in financial reporting as one of qualitative characteristics of accounting information among firms listed in TSE during studied period is in a very low level, contrast with[11] who argue that by passing each year non-operating accruals become significantly smaller, in other word, become more conservative. 


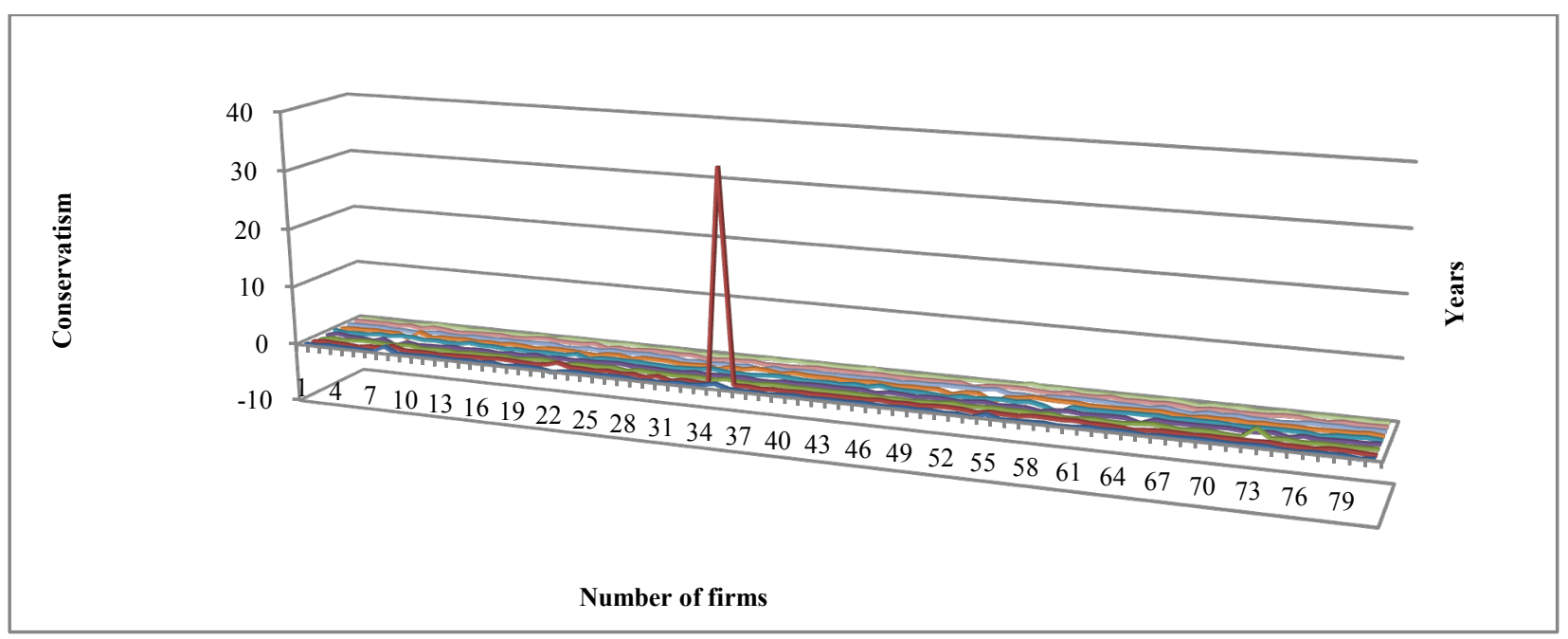

Figure 2. Level of conservatism over time

\section{REFERENCES}

[1] Li, D, (2010). Does auditor tenure affect accounting conservatism? Further evidence. J. Acounting. Public policy 29,226-241.

[2] Nelson, M.W., 2006. Response: Ameliorating conflicts of interest in auditing: Effects of recent reforms on auditors and their clients. Academy of Management Review 31 (1), $30-42$.

[3] Moore, D.A., Tetlock, P.E., Tanlu, L., Bazerman, M.H., 2006. Conflict of interest and the case of auditor independence: Moral seduction and strategic issue cycling. Academy of Management Review 31 (1), 10-29.

[4] .Raiborn, C., Schorg, C.A., Massoud, M., 2006. Should auditor rotation be mandatory? The Journal of Corporate Accounting and Finance 17 (4), 37-49.

[5] Bauwhede,H.W., Willekens, M., Gaeremynck, A. (2003). Audit firm size, public ownership, and firms' discretinary accruals management, The International Journal of Accounting, 38 1-22

[6] DeAngelo, L. E. (1981) Auditor Size and Audit Quality, Journal of Accounting and Economics, 3(3), pp. 183-199.

[7] Hardies, K., Breesch, D., Branson, J. (2011). Are Female Auditors Still Women? Analyzing the sex differences affecting audit quality. available at: http://ssrn.com/abstract=1409964.

[8] Chi, W., Liu, C., Wang, T. (2009). What affects accounting conservatism: A corporate governance perspective, Journal of Contemporary Accounting \& Economics, 47-59.

[9] Basu, S. (1997). 'The Conservatism Principle and the Asymmetric Timeliness of Earnings', Journal of Accounting and Economics, Vol. 24 (December), pp. 3-37.

[10] Watts, R.L., (2002). Conservatism in Accounting, Social Science Research Network Electronic Paper Collection: http://papers.ssrn.com/paper.taf?abstract_id=371820.
[11] Givoly, D. and Hayn, C. (2000) The changing time-series properties of earnings, cash flows and accruals: Has financial reporting become more conservative?, Journal of Accounting and Economics, 29(3), 287-320.

[12] Financial Accounting Standards Board, (1980), Statement of Financial Accounting Concepts No. 2," Qualitative Characteristics of Accounting Information".

[13] Beatty, A., Weber, J., Jiewei J.Y. (2008). Conservatism and Debt, Journal of Accounting and Economics. 154174.

[14] Iyengara, R. J. Zampellib, E.M. (2010). Does accounting conservatism pay? Accounting and Finance, 121-142.

[15] Jensen, M., W. Meckling.(1976). Theory of the firm: Managerial behavior, agency costs, and ownership structure. Journal of Financial Economics 3(4): 305-360

[16] Hamilton, J., Ruddock, C., Stokes, D., \& Taylor, S. (2005). Audit partner rotation, earnings quality and earnings conservatism. Working paper, University of Technology, Sydney and University of New South Wales.[Online] Available: http://ssrn.com/abstract $=7408$ 46.

[17] Li, P.H. (2007). Conservatism and the development of accounting standards. Finance and Accounting Communications (in Chinese).

[18] Jenkins, D.S. Velury. U. (2008). Does auditor tenure influence the reporting of conservative earnings? Journal of Accounting and Public Policy, 27, 115-132.

[19] Chi, W., Wang, C. (2010). Accounting conservatism in a setting of Information Asymmetry between majority and minority shareholders, The International Journal of Accounting, 465-489.

[20] Gao, P. (2011). A Contracting Approach to Conservatism and Earnings Management, The University of Chicago Booth School of Business.

[21] Li, X. (2010). Accounting conservatism and the cost of capital: international analysis, available at: http://ssrn.co $\mathrm{m} /$ abstract $=1261971$.

[22] Ahmeda, K., Henry, D. (2011). Accounting conservatism and voluntary corporate governance mechanisms by 
Australian firms, Accounting and Finance, 1-32.

[23] Kamarudina, K. A, Dunstanb, K., Zijlc, T. (2010). Auditor Tenure, Non-Audit Services and Earnings Conservatism: Evidence from Malaysia: available at: http://ssrn.com/abstract $=1534386$

[24] Davis, R.L., Soo, B.S., Trompeter, G.M., (2009). Auditor tenure and the ability to meet or beat earnings forecasts. Contemporary Accounting Research 26 (2), 517-548.

[25] Lu, T., Sivaramakrishnan, K. (2009). Mandatory audit firm rotation: Fresh look versus poor knowledge, Journal of Accounting and Public Policy, Volume: 28, 71-91.

[26] Fernando, G.D., Elder, R.J., Abdel-Meguid A. M. (2008). Audit Quality Attributes, Client Size and Cost of Capital; available at: $\mathrm{http}: / /$ ssrn.com/abstract $=817286$.

[27] Firth , M., Rui, O.M. Wu, X. 2012. How Do Various
Forms of Auditor Rotation Affect Audit Quality? Evidence from China, The International Journal of Accounting, 47 (2012) 109-131.

[28] Boone, J.P., Khurana, I.K. \& K. Raman, (2010). Do the Big 4 and the Second-tier firms provide audits of similar quality? J. Account. Public Policy 29, 330-352.

[29] Givoly, D, Hayn, C., Natarajan., A. (2007). Measuring reporting conservatism, The Accounting Review, vol. 82, pp. 65-106.

[30] Khurana, I., and K.K. Raman. 2004. Litigation Risk and the Financial Reporting Credibility of Big Four vs. Non-Big Four Audits: Evidence from Anglo-American Countries. The Accounting Review (April): pp. 473-49

[31] Jeong, S.W., Rho, J. 2004. Big Six auditors and audit quality: The Korean evidence, The International Journal of Accounting, 39, 175- 196. 